\title{
ASSESSMENT OF GEOCENTRIC DATUM OF MALAYSIA 2000 (GDM2000)
}

\author{
N. J. Jaffar, T.A. Musa, W.A.W. Aris \\ Geomatic Innovation Research Group, Faculty of Built Environment and Surveying, 80310 Skudai Johor, Malaysia - \\ jehanjaffar@gmail.com, tajulariffin@utm.my,wananom@utm.my
}

KEYWORDS: GDM2000, ITRF2014, vector displacement, MyRTKnet, Sunda plate

\begin{abstract}
:
Several major earthquakes that happened nearby Malaysia for the past decades resulted in a tectonic drift of the Sunda plate. Geocentric Datum of Malaysia 2000 (GDM2000) is affected and has shifted. This paper aims to assess the consistency of GDM2000 by computing datum shift caused by tectonic movement and reference frame effect. Daily solution coordinate of Malaysia Real-Time Kinematic Network (MyRTKnet) stations in the latest reference frame i.e ITRF2014 generated and a coordinate discrepancy between the current reference frame and publish coordinate provided by Jabatan Ukur dan Pemetaan Malaysia (JUPEM) are computed. The result shows that the datum has shifted with an average of $34.6 \mathrm{~cm}$ and moved with an average orientation of $111.1^{\circ}$ toward the southeast direction. Therefore, this study will contribute to giving an overview of the current status of GDM2000.
\end{abstract}

\section{INTRODUCTION}

Geodetic datum unequivocally fixes the relation between reference frame and a reference system by assigning a set of defined parameters comprise of the coordinates of the origin of the Cartesian system $\left(\mathrm{X}_{0}, \mathrm{Y}_{0}, \mathrm{Z}_{0}\right)$, the directions of coordinate axes $\mathrm{X}, \mathrm{Y}, \mathrm{Z}$, and the scale as a unit of length in meter (Drewes, 2009; Angerman et al., 2013). There is various geodetic datum being adopted in mapping and positioning work depends on job specification. Therefore, it is crucial to determine geodetic coordinates of points by postulating the ellipsoid to which the datum refers. Geocentric datum as explained by HofmannWellenhof (2008), represents a best-fit ellipsoid where its origin and orientation are equivalent to the Earth-centred Earth-fixed (ECEF) coordinate system.

The Geocentric Datum of Malaysia 2000 (GDM2000) is a static datum realised by Jabatan Ukur dan Pemetaan Malaysia (JUPEM) back in 2003 for creating a homogeneous coordinate system in Malaysia that compatible with the global reference frame. A total of fifteen (15) Malaysia Active GPS Network (MASS) and eleven (11) International GNSS Service (IGS) stations duration from 1999 to 2002 have been processed to create a zero-order geodetic network for Malaysia. (Kadir et al., 2003) The realisation of GDM2000 is based on International Terrestrial Reference Frame (ITRF2000) at epoch 1 January 2000 by adopting Geodetic Reference System 1980 (GRS80) as reference ellipsoid. However, a study conducted by Shariff (2014) shows that the MyRTKnet stations have undergone land displacement up to 17 and $30 \mathrm{~cm}$ in north and east components respectively, due to a local active fault and the cumulative plate tectonic motion.

Malaysia is a maritime country located in the South-East Asia region. This region is assumed to be part of the stable Eurasian plate derived from a GPS observation network within a small local zone consist of Sumatra, Java, Sulawesi, and Banda arc, that surround the Sunda plate (Tregoning et al., 1994; Genrich et al., 1996). However, a study conducted by Wilson et al (1998) called "Geodynamics of South and Southeast Asia" (GEODYSSEA) has confirmed that Sunda plate is a coherent plate that moves towards east with respect to Eurasia and separated from Siberian platform due to seismic activities (Wilson et al., 1998; Chamote-Rooke and Pichon, 1999; Simon et al., 1999; Michel et al., 2001). A recent study by Simon et al (2007) indicates that the Sunda plate, i.e. Indochina, the western and central part of Indonesia is moving eastward with respect to the Eurasian plate at a velocity of $6 \pm 1$ to $10 \pm 3 \mathrm{~mm} / \mathrm{yr}$ from south to north, respectively.

Sunda Plate is being classified as unstable due to three (3) major earthquakes struck Indonesia, and Malaysia has been affected. Figure 1 shows the locations of $9.2 \mathrm{Mw}$ SumatraAndaman earthquake on 26 December 2004, followed by $8.6 \mathrm{Mw}$ Nias-Simeulue earthquake on 28 March 2005 and $8.5 \mathrm{Mw}$ Bengkulu earthquake on 17 September 2007 (USGS, 2019) caused significant land displacement in this region with magnitude up to $10 \mathrm{~cm}$ for a radius of $400 \mathrm{~km}$ away from the epicentre (Simon et al., 2007; Chlieh et al., 2007; Socquet et al., 2006, Banerjee et al., 2007, Vigny et al., 2005). During the 8.5Mw Bengkulu earthquake, two aftershocks happened within a day with a magnitude of 7.0 Mw and 7.9Mw back in 2007 .

This paper aims to assess the consistency of GDM2000 by analysing the datum shift caused by tectonic movement and reference frame effect. The assessment can be achieved via generating daily solution coordinate of MyRTKnet stations in the latest reference frame i.e. ITRF2014 and analysing coordinate discrepancy between newly generated and publish coordinate provided by JUPEM. 


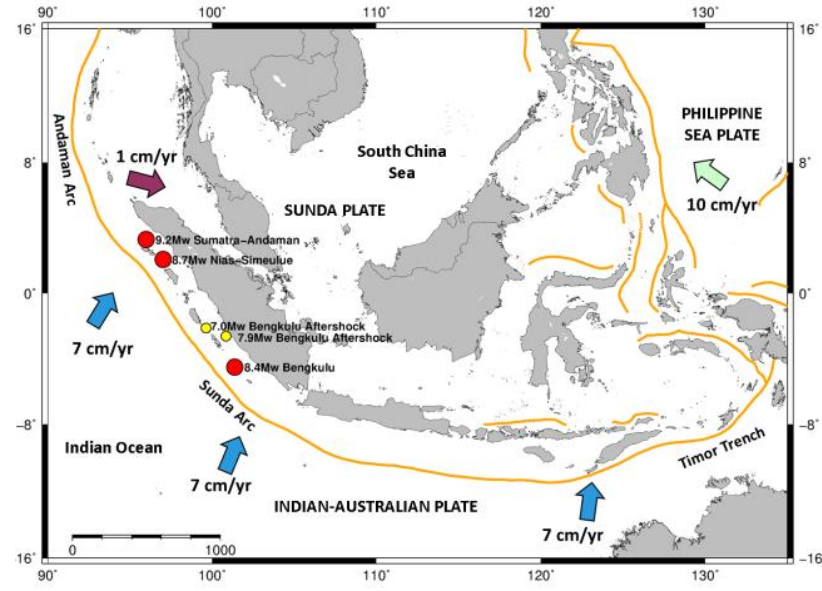

Figure 1. Three (3) major earthquakes and the aftershocks.

\section{GPS MEASUREMENT AND DATA PROCESSING}

\subsection{GPS Network}

The analysed network manages by JUPEM comprises of seventy-eight (78) CORS called MyRTKnet i.e. fifty (50) stations distributed in Peninsular Malaysia and remaining twenty-eight (28) stations located in East Malaysia. In order to assess the compatibility of GDM2000 with the current position, GPS observation data on Date of Year (DoY) 001 until 031 in the year 2014 of these stations are processed with the aid of high precision GNSS Bernese software. In order to realise frame definition in ITRF2014, this network is further extended with twelve (12) globally International GPS Service (IGS) sites treated as fiducial stations as shown in Figure 2.

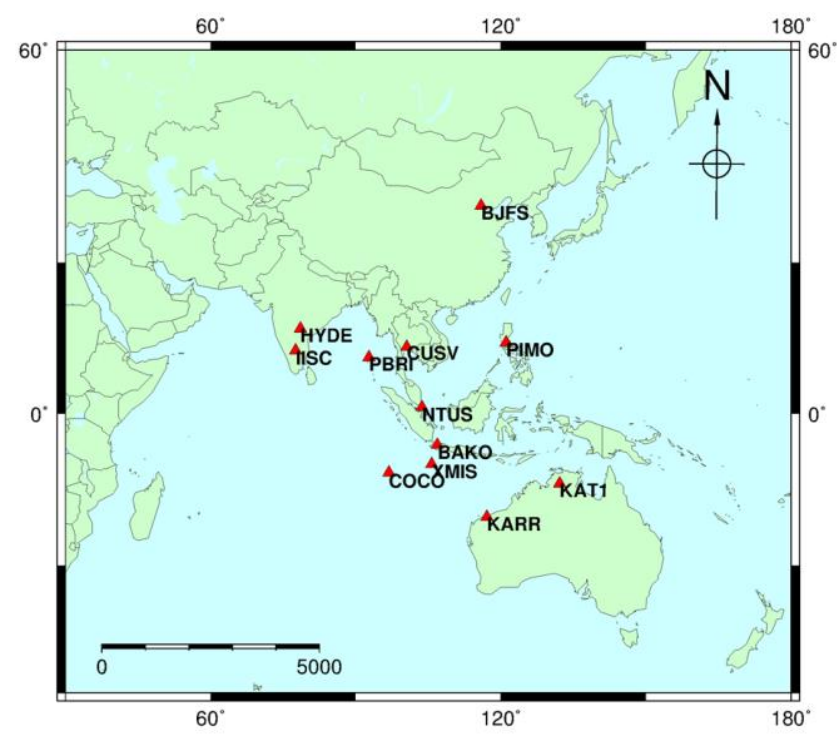

Figure 2. IGS stations adopted in realising frame definition in ITRF2014.

Dual-frequency GPS data from the extended network are processed by applying a Process Control Files (PCF) called RNX2SNX.PCF since it utilises double-difference quasiionosphere free (QIF) network processing strategy (Dach et al., 2015). Adopting this PCF allows reducing distance-dependent errors for short and medium baselines while QIF ambiguity resolution will cater long baselines. Furthermore, as the processing involves GPS data in a regional network and long- term GPS data observation, the minimum constraint approach will be applied. Table 1 summarise several processing strategies and parameters adopted in the Bernese software processing.

\begin{tabular}{|c|c|}
\hline Processing Parameters & Processing Strategy \\
\hline $\begin{array}{l}\text { BPE Process Control } \\
\text { File }\end{array}$ & RNX2SNX.PCF \\
\hline Input Data & Daily RINEX \\
\hline Datum & ITRF2014 \\
\hline Network Baseline & OBX-MAX \\
\hline Elevation Cut-off Angle & $\begin{array}{l}3^{\circ} \text { in CODSPP to first GPSEST } \\
10^{\circ} \text { in first network GPSEST to } \\
\text { final ADDNEQ2 (to reduce } \\
\text { further troposphere effects) }\end{array}$ \\
\hline Sampling Rate & 30 seconds \\
\hline Orbit & IGS Final Orbit (.SP3) \\
\hline $\begin{array}{l}\text { Receiver Antenna Phase } \\
\text { Centre Offsets and } \\
\text { Corrections }\end{array}$ & PHASE_COD.I08 \\
\hline Datum Definition & $\begin{array}{l}\text { Minimum constraint to ITRF2014 } \\
\text { (ADDNEQ2) } \\
\text { Loose constraints in estimating } \\
\text { normal equations (GPSEST) }\end{array}$ \\
\hline Ocean Loading Model & $\begin{array}{l}\text { FES2014b } \\
\text { Double-difference Ionospheric- }\end{array}$ \\
\hline Ionosphere & $\begin{array}{l}\text { Free Linear Combination (L3) } \\
\text { with global ionosphere model }\end{array}$ \\
\hline Ambiguity Resolution & $\begin{array}{l}\text { Fixed, by QIF strategy with } \\
\text { baselines }<2000 \mathrm{~km}\end{array}$ \\
\hline $\begin{array}{l}\text { A Priori Model } \\
\text { (Troposphere) }\end{array}$ & $\begin{array}{l}\text { A-priori Saastamoinen model } \\
\text { with dry Niell mapping function }\end{array}$ \\
\hline Zenith Path Delay & Mapping function: Wet Niell \\
\hline Parameter & Parameter spacing: 2 hours \\
\hline
\end{tabular}

Table 1. Processing strategy and parameters adopted in Bernese processing.

\section{RESULTS AND DISCUSSION}

There are two (2) parts of the results represented in this section to discuss the assessment of the reliability of GDM2000 which are station repeatability and vector displacement of MyRTKnet stations.

Station repeatability of each MyRTKnet station is plotted for quality checking of data processing. Outliers in the data have been removed by using outliers' functional. Figure 3 shows the repeatability of each station in horizontal and vertical components. Outliers in the Northing component for all stations are relatively below $2 \mathrm{~cm}$ except for BELA. The highest value of repeatability in BELA is $2.3 \mathrm{~cm}$. As for the Easting component, the repeatability of each station is below $4 \mathrm{~cm}$ except for BELA with $4.8 \mathrm{~cm}$. The fluctuation of repeatability in the vertical component is larger as compared to horizontal however, the value is below $6 \mathrm{~cm}$ except for BELA with $7.6 \mathrm{~cm}$. This low precision of coordinate repeatability in BELA is due to data gap occurrence during the observation of the following day. 


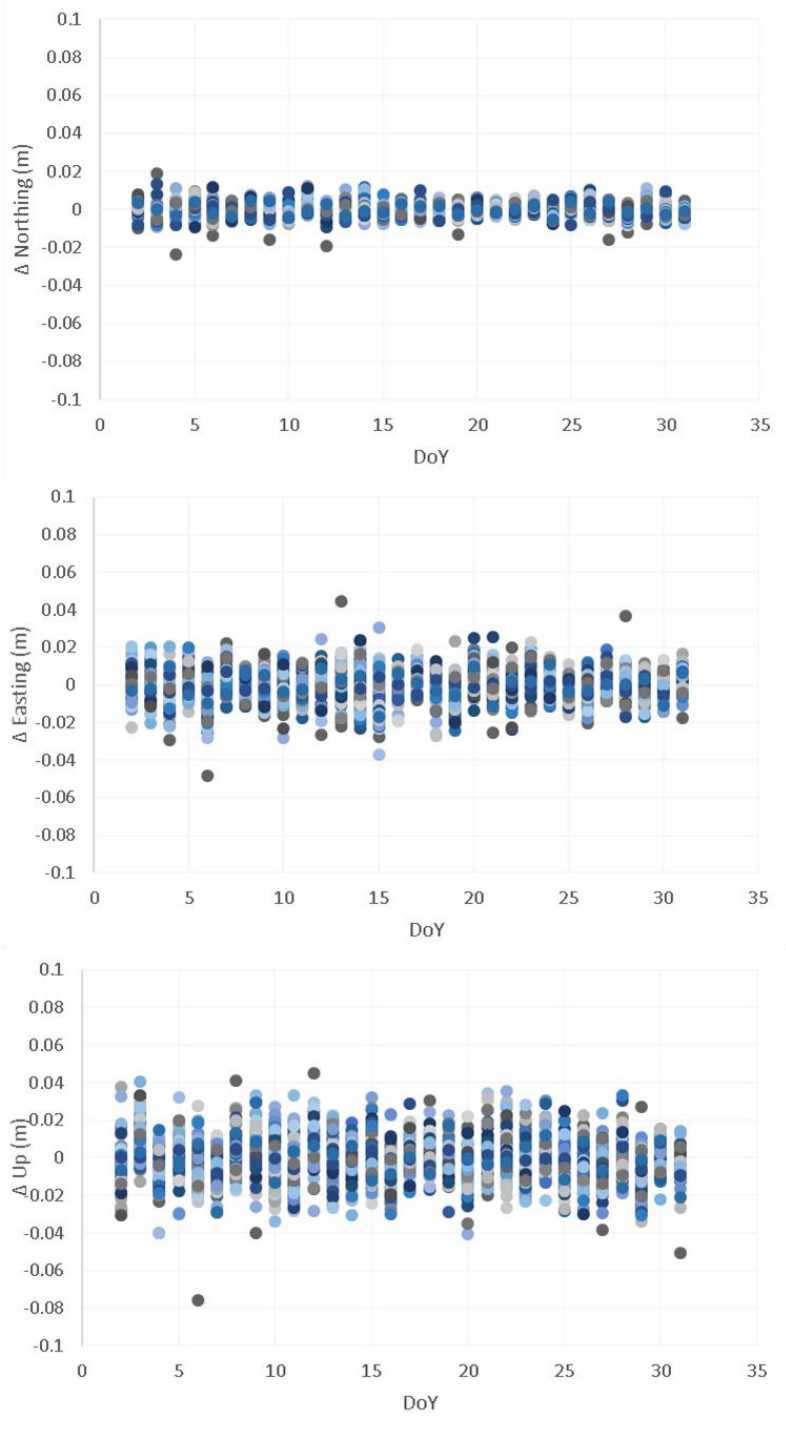

Figure 3. Repeatability of each MyRTKnet station in horizontal and vertical components.

Next, GPS observation data on DoY 001 until DoY 031 are processed to generate thirty-one (31) set of daily solution coordinate. Normal equation stacking is conducted to generate a set of coordinates of epoch $1^{\text {st }}$ January 2014 in ITRF2014. These coordinates are compared to the published set of coordinates of GDM2000 (2006) in ITRF2000 in terms of vector displacements. Figure 4 shows the differences between these two coordinates and can be deduced that the position of MyRTKnet stations moved with an average magnitude of 34.6 $\mathrm{cm}$ and orientation of $111.1^{\circ}$ from GDM2000 (2006) in ITRF2000 to epoch 2014 in ITRF2014.

The stations are separated into several regions as presented in Figure 4. Hence, different patterns of vector displacement can be seen. The first region is stained with blue, consist of stations located in the Northern part of Peninsular Malaysia. The average vector displacement of the blue region is $31.1 \mathrm{~cm}$ magnitude with $110.8^{\circ}$ orientation. On the other hand, LGKW and ARAU possessed slightly different in the orientation of $114.1^{\circ}$ and $115.1^{\circ}$ respectively. This situation can be explained due to the location of these two stations located near to the epicentre of the previous mega-earthquake happened back in
2004 caused the stations to displaced and oriented. The second region is marked green consist of stations in the eastern part of Peninsular Malaysia. The displacement vector of stations is homogeneous with an average magnitude of $33.6 \mathrm{~cm}$ and an orientation of $108.7^{\circ}$. However, station CENE has shown an unusual vector displacement in the vertical component with a magnitude of $12.2 \mathrm{~cm}$.

Further study and analysis of CENE long-term coordinate time series need to be conducted before the conclusion of station subsidence can be made. The third region consists of stations located in the central part of Peninsular Malaysia, mark with red. The station vector is homogenous with an average magnitude of $33.9 \mathrm{~cm}$ and an orientation of $108.6^{\circ}$. Station LIPI and MERU show a relatively larger vector displacement than other stations in terms of the vertical component with a magnitude of $11.6 \mathrm{~cm}$ and $11.4 \mathrm{~cm}$ respectively. Similar to CENE, these stations' movement needs to be further analysed by plotting their long-term coordinate time series. Stations located in the southern part of Peninsular Malaysia are marked with yellow.

This region as compared to others in Peninsular Malaysia has the biggest average station orientation of $112.0^{\circ}$ with an average magnitude of $34.3 \mathrm{~cm}$. No station subsidence detected since the vector displacement in the vertical component of each station is below $8 \mathrm{~cm}$. East Malaysia is marked with purple and orange for Sarawak and Sabah, respectively. The average magnitude vector displacement of all stations in Sarawak is $37.0 \mathrm{~cm}$ with $110.7^{\circ}$ orientation. Though, station AMAN and LAWS have a relatively larger vector displacement and orientation as compared to the average value with $43.8 \mathrm{~cm}$ of orientation $117.3^{\circ}$ and $41.2 \mathrm{~cm}$ of the orientation of $115.2^{\circ}$ respectively.

Station AMAN is believed to be displaced and subsided since the difference between these two epochs in the vertical component is larger as compared to other stations with a magnitude of $26.7 \mathrm{~cm}$. This deduction can be confirmed as the previous study conducted by Gill et al., (2016) has mentioned that AMAN has a different direction and velocity than the others as it experiences severe subsidence as well as study conducted by Aris (2018), the long-term coordinate time series plotted shows that the station has subsided. Nevertheless, station LAWS need to be plotted its long-term coordinate time series to confirm subsidence has occurred here.

Sabah region has the biggest average vector displacement compared to the other five regions with a magnitude of $37.7 \mathrm{~cm}$ and $115.0^{\circ}$ orientation. Six (6) stations i.e. BELU, LAB1, MRDU, RANA, TENM, and TMBN displaced more than $40 \mathrm{~cm}$ with $116^{\circ}$ orientation. this situation can be explained due to Sabah is located close to the most seismically active plate boundaries between the Indian-Australian plate and Eurasian plate in the west and between the Philippine plate in the east (Tongkul, 2017). 
The International Archives of the Photogrammetry, Remote Sensing and Spatial Information Sciences, Volume XLII-4/W16, 2019 6th International Conference on Geomatics and Geospatial Technology (GGT 2019), 1-3 October 2019, Kuala Lumpur, Malaysia

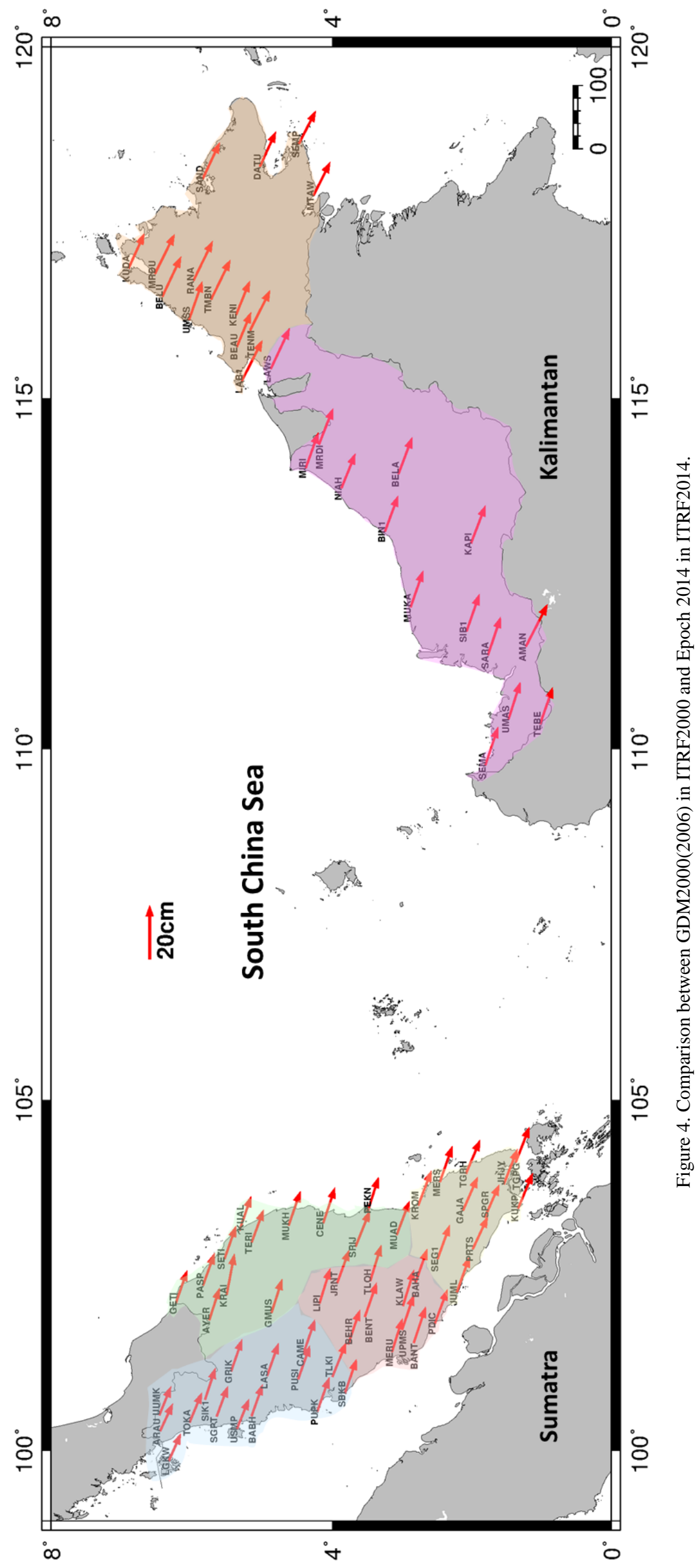

This contribution has been peer-reviewed. 


\section{CONCLUSION}

This paper shows that the MyRTKnet stations adopted GDM2000 (2006) in ITRF2000 have displaced and there is a coordinate discrepancy between the current ITRF2014 reference frame and GDM2000 (2006). The coordinate discrepancies are relatively larger with an average of $34.6 \mathrm{~cm}$. Coordinate discrepancies of most of the stations are caused by the tectonic movement of the Sunda plate. Furthermore, certain stations are not solely caused by the tectonic movement since soil movement could be one of the factors contributing to station displacement.

This situation may lead to several implications such as inconsistent satellite orbit and coordinate bias as well as problems in surveying and mapping. The mm-level accuracy of the reference station coordinate will also degrade causes the coordinate of the reference station to be unreliable. Eventually, scientific application and research will be affected. It is suggested for further studies to involve long-term GPS observation data for coordinate time series to be analysed for better understanding regarding station displacement.

\section{ACKNOWLEDGEMENTS (OPTIONAL)}

The author would like to express gratitude toward Jabatan Ukur dan Pemetaan Malaysia (JUPEM) in providing MyRTKnet data for this study. The author also would like to channel an appreciation towards Kementerian Pengajian Tinggi (KPT) and Fundamental Research Grant Scheme (FRGS) - Vote No. R.J130000.7827.4F962 for funding this study.

\section{REFERENCES}

Drewes, H., 2009: Reference Systems, Reference Frames and the Geodetic Datum - Basic Considerations. In: Sideris, M.G., (Ed.). Observing our Changing Earth, International Association of Geodesy Symposium 133., 1-9. Berlin Heidelberg: Springer-Verlag.

Angermann, D., Manuela, S., and Drewes, H., 2013: Global Terrestrial Reference Systems and Their Realizations. In: Xu, G. (Ed). Science of Geodesy - II Innovations and Future Developments. Springer Berlin Heidelberg.

Hofmann-Wellenhof, B., Lichtenegger, H. and Walse, E., 2008: GNSS Global Navigation Satellite Systems GPS, GLONASS, GALILEO and more. Austria: Springer Wein New York.

Kadir, M., Ses, S., Omar, K., Desa, G., Omar, A.H., Taib, K., and Nordin, S., 2003: Geocentric Datum GDM2000 for Malaysia: Implementation and Implications. Seminar on GDM2000, Department of Survey \& Mapping Malaysia. 28 August, Kuala Lumpur, Malaysia.

Tregoning, P., Brunner, F.K., Bock, Y., Puntodewo, S.S.O., McCaffrey, R., Genrich, J.F., Calais, E., Rais, J., and Subaraya, C., 1994: First Geodetic Measurement of Convergence Across the Java Trench, Geophys. Res. Lett. 21. 2135-2138.

Genrich, J., Bock, Y., McCaffrey, R., Calais, E., Stevens, C., and Subarya, C., 1996: Accretion of the Southern Banda Arc to the Australian Plate Margin Determined by Global Positioning System Measurement. Tectonics 15(2). 288-295.
Wilson, P., et al. 1998: Study Provides Data on Active Plate Tectonics in Southeast Asia Region. Eas Trans AGU, 79(45). 545-549.

Chamote-Rooke, N. and Pichon, X.L., 1999: GPS Determines Eastward Sundaland Motion with respect to Eurasian Confirmed by Earthquake Slip Vectors at Sunda and Philippine Trenches. Earth Planet. Sci. Lett., 173(439-455).

Simon, W.J.F., Ambrosius. B.A.C., Noomen, R., Angermann, D., Wilson, P., Becker, M., Reinhart, E., Walpersdorf, A., and Vigny, C., 1999: Observing Plate Motions in S.E. Asia: Geodetic Results of the GEODYSSEA Project. Geophys. Res. Lett., 26(14), 2081-2084.

Michel, G. W., Yua, Y. Q., Zhua, S. Y., Reigber, C., Becker, M., Reinhart, E., Simons, W., Ambrosius, B., Vigny, C., Chamot-Rooke, N., Pichond, X., Morgane, P. and Matheussene, S., 2001: Crustal Motion and Block Behaviour in SE-Asia from GPS Measurements. Earth and Planetary Science Letters. 187 (3-4), 239244. Elsevier.

Simons, W., Socquet, A., Vigny, C., Ambrosius, C., Abu, S., Promthong, C., Subarya, C., Sarsito, D. A, Matheussen, S., Morgan, P. and Spakman, W., 2007: A Decade of GPS in Southeast Asia: Resolving Sundaland Motion and Boundaries. Journal of Geophysical Research. 112 (B06420). AGU Publications.

Chlieh, M., Avouac, J., Hjorleifsdottir, V., Song, T. A., Ji, C., Sieh, K., Sladen, A., Hebert, H., Prawirodirdjo, L., Bock, Y. and Galetzka, J., 2007: Coseismic Slip and Afterslip of the Great Mw9.15 Sumatra-Andaman Earthquake of 2004. Bulletin of the Seismological Society of America. 97 (1A), 152-173.

Socquet, A., Vigny, C., Chamot-Rooke, N., Simons, W., Rangin, C. and Ambrosius, B., 2006: India and Sunda Plates Motion and Deformation along their Boundary in Myanmar Determined by GPS. Journal of Geophysical Research. 111 (B05406). AGU Publications.

Banerjee, P., Pollitz, F., Nagarajan, B., and Bürgmann, R., 2007: Coseismic Slip Distributions of the 26 December 2004 Sumatra-Andaman and 28 March 2005 Nias Earthquakes from GPS Static Offsets. Bulletin of the Seismological Society of America. 97 (1A), 86-102.

Vigny, C., Simons, W. J. F., Abu, S. H., Ronnachai, B., Satirapod, C., Chhoosakul, M., Subarya, C., Omar, K., Abidin, H. Z., Socquet, A. and Ambrosius, B. A. C., 2005: Insight into the 2004 Sumatra-Andaman earthquake from GPS measurements in Southeast Asia. Nature. 436, 201-206.

Dach, R., Hugentobler, U., Fridez, P. and Meindl, M., 2007: Bernese GPS Software Version 5.2 Switzerland: Astronomical Institute, University of Bern.

Gill, J., Shariff, N.S., Omar, K.M., Din, A.H.M., and Amin, Z.M., 2016: Development of a Time-Dependent 3-Parameter Helmert Datum Transformation Model: A Case Study for Malaysia. The International Archives of the Photogrammetry, Remote Sensing and Spatial Information Sciences. Vol. XLII4/W1. 2016 International Conference on Geomatic and Geospatial Technology (GGT) 2016 on 3-5 October, Kuala Lumpur, Malaysia. 
Tongkul, F., 2016: The 2015 Ranau Earthquake: Cause and Impact. Sabah Society Journal, 32, 1-28.

Shariff, N. S. M., Musa, T. A., Omar, K., and Othman, R., 2014: The Geocentric Datum of Malaysia: Preliminary Assessment and Implications. Geoinformation for Informed Decisions. Springer International Publishing. 71-83.

Aris, W.A.W., 2018: Spatio-Temporal Crustal Deformation Model of Sundaland in Malaysia using Global Positioning System. UTM thesis. 206-229.

Shariff, N.S., 2018: Semi-Dynamic Geocentric Datum for Positional Accuracy and Reliability in Malaysia. UTM thesis.

USGS, 2019. Earthquake Catalog, https://earthquake.usgs.gov/earthquakes/search/ (14 May 2019).

Jabatan Ukur dan Pemetaan Malaysia, 2009: Technical Guide to the Coordinate Reference System. Pekeliling KPUP Bil 1/2009. Kuala Lumpur Malaysia.

Wessel, P. and Smith, W.H.F., 1998: New Version of the Generic Mapping Tools Released. Eos Trans. AGU. 79(47), 579 .

Revised August 2019 